\title{
Clay mineralogy and geochemistry of some black, red and red laterite soils in semi arid tropical region of Tamil Nadu
}

\section{RAJESHWAR MALAVATH AND S.MANI}

Received : 21.01.2017; Revised : 06.05.2017; Accepted : 19.05.2017

MEMBERS OF RESEARCH FORUM:

Corresponding author : RAJESHWAR MALAVATH, Department of Soil Science and Agricultural Chemistry, College of Agriculture, Prof. Jayashankar Telangana State Agricultural University, Rajendranagar, HYDERABAD (TELANGANA) INDIA Email: rajeshoct31naik@gmail.com

Co-authors :

S. MANI, Department of Soil Science and Agricultural Chemistry, Agricultural College and Research Institute, Tamil Nadu Agricultural University, COIMBATORE (T. N.) INDIA

\section{Summary}

The X-ray diffraction pattern of soil clay fraction of one red soil pedon from Maize Research Station, Vagarai of Dindigul district, one black soil pedon from Cotton Research Station, Veppanthatai (Perambalur district) and one red laterite soil from Dryland Agricultural Research Station, Chettinad of Sivaganga district of Tamil Nadu was carried out to distinguish the distribution of clay minerals by using X-ray diffraction method and the mineral composition was assessed semiquantitatively. The black soil pedon revealed the dominance of smectite in association with small quantities of illite and kaolinite. The red soil pedon clay faction was "mixed" with smectite, illite and kaolinite type of clay minerals. The dominant clay mineral was kaolinite with small quantities of illite in red laterite soils pedon. The chemical composition of soils exhibited the siliceous nature with broad and large silica/sesquioxides and silica/ alumina ratios. The wider ratios of $\mathrm{SiO}_{2} / \mathrm{R}_{2} \mathrm{O}_{3}$ and $\mathrm{SiO}_{2} / \mathrm{Al}_{2} \mathrm{O}_{3}$ (4.64 to 5.61 and 5.75 to 6.94) were found in the black soils pedon followed by red soils pedon (4.55 to 5.01 and 7.78 to 9.64 ), respectively where smectite and illite were the dominant clay minerals. The narrow silica/ sesquioxides and silica/alumina ratios (2.23 to 2.56 and 4.13 to 5.37) were found in red laterite soils where Kaolinite was dominant clay mineral in semi arid tropical region of Tamil Nadu.

Key words : Black soils, Red soils, Red laterite soils, Clay mineral, X-ray diffraction, Elemental composition

How to cite this article : Malavath, Rajeshwar and Mani, S. (2017). Clay mineralogy and geochemistry of some black, red and red laterite soils in semi arid tropical region of Tamil Nadu. Asian J. Soil Sci., 12 (1) : 162-173 : DOI : 10.15740/HAS/AJSS/12.1/162-173. 